\title{
Professional Positions on Online Psychosocial Care in Canada: A Review of Current Policy Statements
}

\author{
Adina Rojubally and Joanne Stephen \\ British Columbia Cancer Agency \\ Karen Fergus \\ Sunnybrook Odette Cancer Centre and York University \\ Scott Sellick \\ Thunder Bay Regional Health Sciences Centre \\ Deborah McLeod \\ Dalhousie University \\ Michael Speca \\ Tom Baker Cancer Centre \\ Jill Taylor-Brown \\ Cancer Care Manitoba \\ Kate Collie and Jill Turner \\ Cross Cancer Institute
}

Adina Rojubally, Provincial Psychosocial Oncology Program, British Columbia Cancer Agency; Joanne Stephen, Provincial Psychosocial Oncology Program, British Columbia Cancer Agency; Karen Fergus, Department of Psychology, York University and Sunnybrook Odette Cancer Centre; Scott Sellick, Supportive Care, Thunder Bay Regional Health Sciences Centre; Deborah McLeod, School of Nursing, Dalhousie University; Michael Speca, Department of Psychosocial Resources, Tom Baker Cancer Centre; Jill Taylor-Brown, Patient and Family Support Services, Cancer Care Manitoba; Kate Collie, Cross Cancer Institute; Jill Turner, Cross Cancer Institute.

This project was generously funded by the Canadian Partnership Against Cancer (CPAC). Special thanks to Mai Elramly, Kate MacGregor and NAPSCO members.

There are no conflicts of interest present with the authors of this paper.

Correspondence concerning this article should be addressed to Adina Rojubally, British Columbia Cancer Agency, Fraser Valley Centre, Patient and Family Counselling Services, 13750 96th Avenue, Surrey, BC V3V 1Z2. E-mail: arojubally@bccancer.bc.ca 


\begin{abstract}
With the advent of online mental health care, concerns related to online practice are emerging among mental health professionals. This paper assesses and organizes the current status of several professions in Canada - including medicine, nursing, psychology, counselling, and social work — on the issue of practice via the internet, so that these professions may be productively compared and considered. Psychology, social work, and counselling have few stated e-health policies within their regulatory colleges, and those that do exist are conservative and tend towards restricting mental health practice online. The remaining hurdle for e-health, including online psychosocial care development, is cross-provincial practice - which, in turn, appears to rest on the definition of "where therapy resides" in the event of legal action.
\end{abstract}

Keywords: e-health, mental health online, policy, guidelines, standards, cross-provincial practice

\title{
RÉSUMÉ
}

Avec l'avènement des soins de santé mentale en ligne, les questions liées à la pratique en ligne commencent à émerger parmi les professionnels et professionnelles de santé mentale. Ce document évalue et organise l'état actuel de plusieurs professions au Canada comme la médecine, les soins infirmiers, la psychologie, le travail social et le counseling sur la question du pratique sur internet afin qu'ils puissent être comparés de façon productive et réfléchie. Les organismes de réglementation des disciplines de la psychologie, du travail social et du counseling ont indiqué peu des politiques sur la cybersanté, et celles qui existent sont conservatrices, tendant à restreindre la pratique de la santé mentale en ligne. L'obstacle restant pour la cybersanté, y compris le développement des soins psychosociaux en ligne, est celui de la pratique interprovinciale, qui à son tour semble reposer sur la définition d'« où réside la thérapie » dans le cas d'une action en justice.

Mots clés : cybersanté, santé mentale en ligne, politique, directives, normes, pratique interprovinciale

It is hereby declared that the primary objective of Canadian health care policy is to protect, promote and restore the physical and mental well-being of residents of Canada and to facilitate reasonable access to health services without financial or other barriers.

—Canada Health Act (Canada, 1984/1985)

Supporting the recovery and integration of individuals with serious mental illness or physical disability into the community has been identified as a priority in Canada (Kates, Gagné, \& Whyte, 2008; Mulvale \& Bartram, 2009). A recent independent pan-Canadian study on telehealth reported that mental health and addictions make up 54\% of the reported telehealth services across Canada (Canada Health Infoway, 2011). With the advancement of technology and the corresponding proliferation of the internet, the remote delivery of health services (now more commonly referred to as e-health) is increasing. With more and more people turning to the internet for support and counselling, mental health professionals are not only becoming increasingly concerned about the safety and effectiveness of the services being used, but they are also worrying about the legal implications of web-based practices (Lester, 2006; Skinner \& Latchford, 2006; Wells, Mitchell, Finkelhor, \& Becker-Blease, 2007). In this new environment, practitioners are looking to professional associations, licensing boards, and government oversight agencies for up-dated, consistent, well-developed practical and ethical practices to guide the provision of services (Shaw \& Shaw, 2006). 
This study was prompted by our own efforts to mount a pan-Canadian initiative to offer high-quality, professionally led online support groups (OSGs) to all individuals living in Canada who are affected by cancer (Stephen et al., 2013). Although the availability of community-based psychosocial support for patients and caregivers has grown exponentially in the past decade, there remain many individuals for whom these services are inaccessible. Barriers include: (a) living in rural or remote regions where support services are not available; (b) significant physical disability related to pain or fatigue; and/or (c) reduced mobility due to the effects of treatment or to disease progression. Moreover, a number of people shy away from face-to-face support groups and prefer the anonymity and freedom of expression afforded to them through the online modality (Hoybye, Johansen, \& Tjornhoj-Thomsen, 2005; Pfeil \& Zaphiris, 2010; Stephen et al., 2013).

Thus, the objective of our work rests heavily on Canada's health care mandate for equitable access of care by Canadians. Unfortunately, the pan-Canadian vision we share with the stakeholders is being hampered by the different psychology, social work, and counselling policies which are emerging in some provinces. Because of these policies, the outreach of online psychosocial resources from one regional cancer centre to centres and/or individuals in other provinces is hindered. Although we approached this study from the vantage point of professionally delivered OSGs for individuals affected by cancer, our broader aim is to contribute to the larger conversation on pan-Canadian online mental health care delivery, and to reduce encumbrances to accessing these services.

\section{Emergence of Online Psychosocial Care}

When online counselling began to take hold in the 1990s, concerns arose related to two broad questions: (a) can online services be delivered safely and ethically; and (b) can they be as effective as face-to-face services (Alleman, 2002)? Now that the internet has become an everyday means of communication and a commonplace tool in general clinical practice, those initial concerns have dissipated. Licensed counsellors, mental health nurses, social workers, and psychologists now use e-mail, text chat, interactive websites, videoconferencing, electronic bulletin boards, and other internet tools in their clinical practice (Barak, Klein, \& Proudfoot, 2009).

Ethical guidelines for online counselling have been discussed and refined over the years (Derrig-Palumbo, 2009; Fox \& Purcell, 2010; Mallen, Vogel, \& Rochlen, 2005; National Initiative for Telehealth Guidelines, 2003; Shaw \& Shaw, 2006). In North America, the first "Standards for Ethical Web Counselling" were issued in 1998 by the National Board of Certified Counselors in the United States (Bloom, 1998). These guidelines - which were developed by a team of counselling professionals that included Canadians - formed the basis for the subsequent development of ethical guidelines by professional organizations around the world, including the Canadian Society for Telehealth.

There are several reviews and meta-analyses which conclude that internet interventions deliver positive outcomes, primarily in the area of improved health-related quality of life (Rains \& Young, 2009), including reduced social isolation, enhanced coping, and improved mood (Fernsler \& Manchester, 1997; Houston, Cooper, \& Ford, 2002; Lieberman et al., 2005; Seale, 2006; Sharf, 1997; Stephen et al., 2013; Sullivan, 2003; Winzelberg et al., 2003). Online support is valued by internet users because it is convenient, can be accessed from anywhere and at any time, and provides privacy (Fernsler \& Manchester, 1997; Finfgeld, 
2000; Gustafson et al., 2001; Gustafson et al., 1994; Klemm et al., 2003; McTavish et al., 1995; Sharf, 1997; Weinberg, Schmale, Uken, \& Wessel, 1995; Weinberg, Schmale, Uken, \& Wessel, 1996). Research about professionally led OSGs for people with cancer has provided evidence that these groups can be as effective as in-person groups (Lieberman \& Golant, 2002; Lieberman et al., 2003; Winzelberg et al., 2003).

Safety and ethical issues can be successfully navigated (Derrig-Palumbo, 2009; Maheu, 2003; Shaw \& Shaw, 2006) and efficacy studies are emerging and supportive. However, the jurisdictional issue remains: internet practice is inherently pan-Canadian, whereas professional regulatory bodies are provincial, causing the locus of accountability and responsibility to become blurred (Mallen et al., 2005). Mental health professionals want to be responsive to burdened populations regardless of where they live, but are unsure of policies regarding online practice. They are interested in learning what their colleagues are doing to meet needs of underserved populations.

Our objective in this paper is to assess the current status of the professions - specifically with respect to determining who can participate in online psychosocial care and what issues are raised by cross-jurisdictional practice. Because of its comparatively long history, we will also consult the literature on "telemedicine" (the delivery of health services via video link to remote areas by doctors and nurses) in the hope that we will find that this practice has well-developed policies and guidelines upon which we can draw. Ultimately, our goal is to collate and organize the relevant findings on policy statements and e-health practice guidelines across different professional bodies in Canada so they may be productively compared and considered.

\section{METHODS}

\section{Definitions}

The terms e-counselling, e-therapy, and e-health are used throughout this document to refer to the online provision of health care services including mental health. Telehealth is used to describe other methods of telecommunications such as phone or video teleconferencing. Telehealth methods used for access to or delivery of mental health services are referred to as telemental health. Telemedicine is predominantly associated with the medical field and, although that is not the main focus of this paper, we include mention of it as a way of capturing the range of technologies used to bridge distance between patients/consumers and professional psychosocial services.

\section{Sources and Analysis for Medicine and Nursing}

For this paper, the following types of information were reviewed and analyzed: (a) available policies and guidelines of regulatory bodies involved in telehealth or e-health including behavioral healthcare services; (b) peer-reviewed and non-peer-reviewed literature (e.g. government reports); and (c) interviews with nine key informants who are associated with regulatory bodies involved in the provision of mental health services in Canada.

Since the medical and nursing professions were the pioneers of health care delivery without borders, known as telemedicine, we hoped their progress in the field could be extended to mental health online. For medical and nursing professions, the regulatory bodies' websites were explored for policies, guidelines, or statements relevant to online practice. For medicine, information was retrieved from a policy statement from 
the national regulatory body and from nine telemedicine documents from the provincial regulatory colleges. For nursing, a position statement from the national association and five practice guidelines on telehealth or telenursing were analyzed.

\section{Sources and Analysis for Psychology, Social Work and Counselling}

Online scan. An online scan was conducted to explore the licensure requirements of various professions that may be involved in the delivery of online behavioral healthcare services including OSGs across provincial boundaries. The professional licensure, standards, and practice guidelines for internet health care delivery were explored for the fields of psychology, counselling, and social work. Within these fields, once we located the regulatory colleges, we examined the websites for policies regarding e-health. If a national board or college was not identified for a particular profession, we searched for federal or provincial policies or guidelines. Where e-health policies were identified, we reviewed any exposition of licensure for online delivery of care including: standards of practice, complaint resolution, patient safety, or protection of personal health information. For social workers, we retrieved information from three documents from the provincial associations or colleges. In the case of counsellors and psychologists, we identified and reviewed only two documents; whereas from the national and international websites (including governmental bodies), we reviewed nine non-peer-reviewed literature documents or reports.

Key informant interview. When no clear practice guidelines were identified, we identified the key informants from each Canadian advisory or regulatory organization in psychology, social work, and counselling either by referral or by exploring their websites. We then contacted these individuals by e-mail and invited them to respond to the questions below (either via e-mail or telephone). The interviews were conducted by one of the authors (JS). The questions below were used to guide the e-mail or telephone interviews:

1. Does your organization currently have a position with regard to professionals facilitating online support groups that serve clients from multiple provinces and/or territories? If so, what is it?

2. Is there a current working group or task force that aims to address issues regarding the use of technology (i.e. internet interventions) when delivering services? And if so, when do you expect a resolution?

3. Is there a contact person for these initiatives?

4. Are you currently accepting any recommendations?

5. Do you have any other helpful comments for us?

Of the 26 requests, only 9 (social work $=4$, counselling $=2$, and psychology $=3$ ) responded.

\section{RESULTS}

\section{Review of Medical and Nursing Positions}

The Federation of Medical Regulatory Authorities of Canada (FMRAC) (2010) has yet to achieve a national consensus on licensure for telehealth practice; however, it does have a Telemedicine Policy with guidelines and recommendations, which urges each medical regulatory authority to publish requirements 
for provision of telemedicine. By delegating the task to the respective provinces, FMRAC has created an intrinsic divide in the development of policies. The various forms of policies range from the most restrictive in the case of Alberta (College of Physicians and Surgeons of Alberta, 2000), where physicians providing services to recipients located in that province must be licensed and registered in Alberta and pay a required fee, to the more inclusive Quebec position statement (Collège des Médecins du Québec, 2000), which states that in the practice of telemedicine, the medical act is performed in the place where the physician being consulted practises, and not in the place where the patient is (Figure 1).

The Canadian Nurses Association (CNA) (2007) released a position statement related to nursing practice and telehealth in 2007. The statement consists of a framework for principles that are critical to nurses providing safe, ethically sound, and competent telehealth or e-health services. The licensure model endorsed by CNA dictates that nurses engaged in e-health or telehealth are considered to be practising in the province or territory in which they are located and currently registered, regardless of where the client is located. This

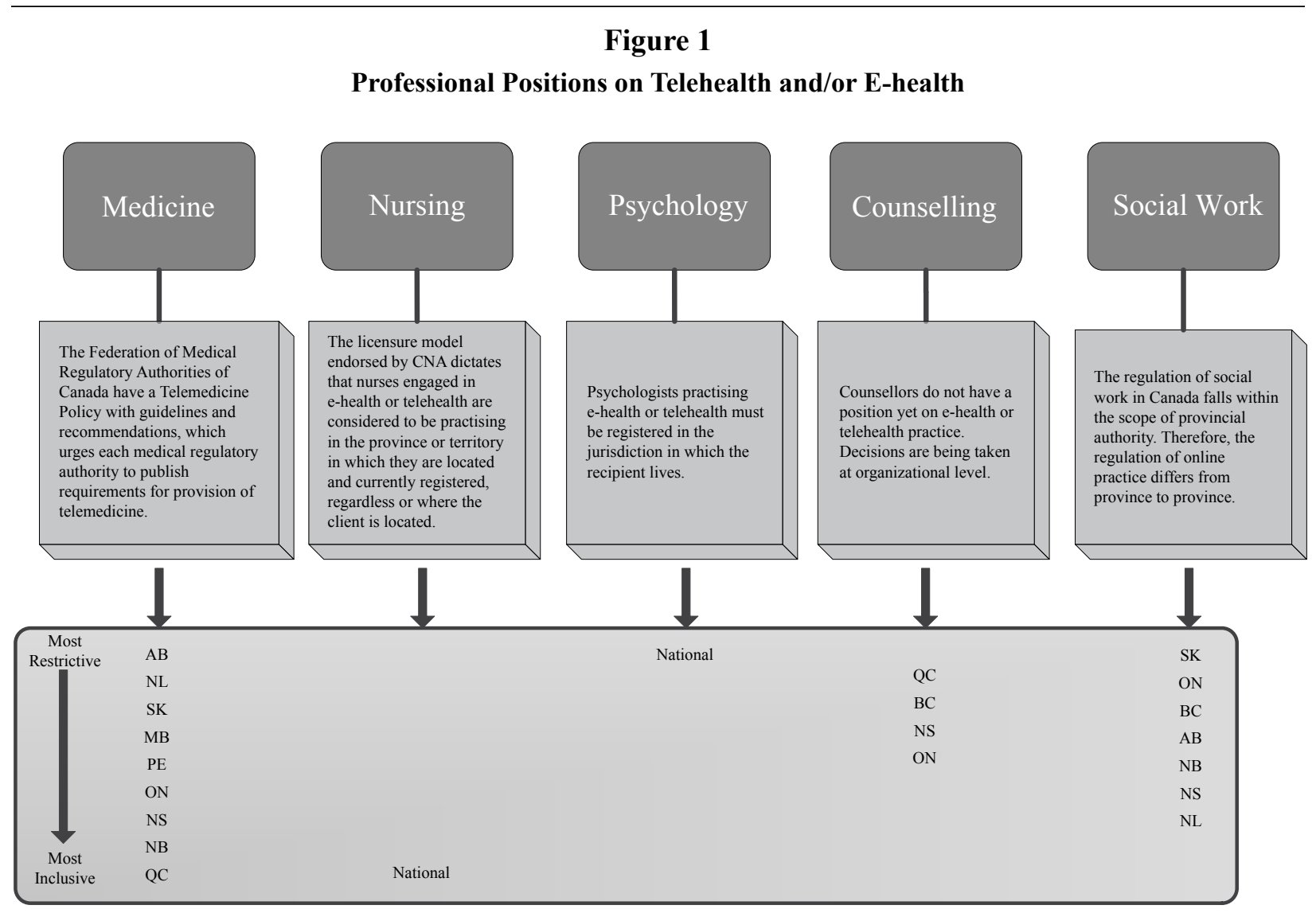

Note. The figure represents the current status of several professions including medicine, nursing, psychology, counselling, and social work on the issue of practice via the internet or other remote-care delivery. The professional positions range from the most restrictive to the most inclusive based on policy statements or practice guidelines endorsed at a national or provincial level. 
statement by the nursing association has united the different regulatory bodies towards a coordinated policy and workable guidelines for nursing practice via technology (Figure 1).

\section{Environmental Scan of Psychosocial Professions}

This environmental scan brings new information about psychosocial professions and how jurisdictional barriers are hindering good patient care. The jurisdictional issues are addressed in light of online support groups and the challenges pertaining to the delivery of the service at a national level. The practice guidelines, provincial requirements, and position statements identified for professionals involved in online practice are described in Table 1.

Social work. In Canada, social work legislation is the responsibility of the provinces. In six provincesAlberta, Saskatchewan, Manitoba, New Brunswick, Nova Scotia, and Newfoundland and Labrador - the regulatory body and professional association are under the same umbrella. Although our search for practice guidelines for social workers yielded few hits on the provision of online services (Alberta College of Social Workers, 2007; New Brunswick Association of Social Workers, 2010; Nova Scotia Association of Social Workers, 2008), communication with key informants allowed us to understand their position and their endeavours to address cross-jurisdictional practice at a provincial level (Table 1).

The regulatory environment for social workers is complex in Canada, and even in provinces with regulation, not all social workers may be required to register with a provincial regulatory authority as a condition of practice. Since the regulation of online practice differs from province to province, this has inevitably created a disjointed system (Figure 1).

In Alberta, British Columbia, Nova Scotia, and New Brunswick, social workers who use telephonic or other electronic means to provide services have to abide by all the regulations of their professional practice with the understanding that their practice may be subject to regulation in both the jurisdiction in which the client receives services and the jurisdiction in which the social worker provides the services. In Saskatchewan and Ontario, an intending online practitioner using the title social worker who seeks to deliver services to residents of the province from an out-of-province location is expected to first gain registration with the college (Table 1). On the other hand, there are no barriers preventing a social worker registered in Newfoundland and Labrador from engaging in online counselling (Table 1).

No policies or guidelines on online practice could be identified for the colleges or associations of Manitoba, Quebec, and Prince Edward Island. We could not establish contact with key informants from these organizations.

Counselling. The counselling profession is debating the regulation of the profession. There is a great deal of activity ongoing across provinces and the landscape regarding counselling is rapidly evolving. Currently in Canada, the provinces where the professions of counselling and/or psychotherapy are regulated (or are being regulated) are Quebec, Ontario, and Nova Scotia (Canadian Counselling and Psychotherapy Association, 2011). Nonetheless, e-mail communications with the respective associations or colleges were initiated to understand their current position on online counselling (Table 1). Indeed there is currently an absence of regulation in relation to online practice, which may be a blessing in disguise for counsellors involved in online practice. However, some provinces are undecided with regard to e-counselling because of lack of agreement on the legal issue of "where therapy resides." 


\section{Table 1}

\section{Technology in Practice: Guidelines and Requirements for Practitioners}

\begin{tabular}{ll}
\hline Province & Social Workers \\
\hline British & Social workers are advised \\
that when they are provid- & ing services to clients in \\
other jurisdictions, they must & meet the regulatory require- \\
& ments in those other jurisdic- \\
& tions. This often means they \\
& are supposed to be registered/ \\
& licensed in the other juris- \\
& diction. British Columbia \\
& has not adopted any specific \\
& policy regarding the provi- \\
& sion of online services by \\
& social workers. \\
British Columbia College of & Social Workers \\
(e-mail received on March & 23, 2011)
\end{tabular}

Counsellors

Although the recently adopted standard for the use of technology in counselling in B.C. recognizes the potential of technology as a useful tool for therapists in assisting their clients, and also addresses the special issues raised by the use of technology, their policy statement suggests avoidance of online practice as a ongoing practice.

As there is no legal ruling as to whether telephone or internet counselling takes place in the counsellor's location or the client's location, registered clinical counsellors need to review local laws and customs in both their own area and in the area where the client resides.

\section{British Columbia Associa-} tion of Clinical Counsellors (BCACC), 1996 and 2011

No correspondence or identified guidelines on e-health
Psychologists

No correspondence or identified guidelines on e-health

Alberta

Practice may be subject to regulation in both the jurisdiction in which the client receives services and the jurisdiction in which the social worker provides the services. Alberta College of Social Work, 2007 


\section{Table 1}

(continued)

\begin{tabular}{|c|c|c|c|}
\hline Province & Social Workers & Counsellors & Psychologists \\
\hline Saskatchewan & $\begin{array}{l}\text { An intending online practi- } \\
\text { tioner seeking to deliver ser- } \\
\text { vices to Saskatchewan-based } \\
\text { residents from an out-of- } \\
\text { province location, using the } \\
\text { title social worker, must first } \\
\text { gain registration with SASW. } \\
\text { Since no specific working } \\
\text { group or task force has yet } \\
\text { been dedicated to e-practice, } \\
\text { regulatory adjustments will } \\
\text { come in response to questions } \\
\text { and issues now arising from } \\
\text { the emerging use of technol- } \\
\text { ogy in delivering health and } \\
\text { social services. } \\
\text { Saskatchewan Association } \\
\text { of Social Workers } \\
\text { (e-mail response on April 4, } \\
\text { 2011) }\end{array}$ & $\begin{array}{l}\text { No correspondence or identi- } \\
\text { fied guidelines on e-health }\end{array}$ & $\begin{array}{l}\text { No correspondence or identi- } \\
\text { fied guidelines on e-health }\end{array}$ \\
\hline
\end{tabular}

Manitoba No correspondence or identi-

No correspondence or identified guidelines on e-health
No correspondence or identified guidelines on e-health 
Table 1

(continued)

\begin{tabular}{|c|c|c|c|}
\hline Province & Social Workers & Counsellors & Psychologists \\
\hline Ontario & $\begin{array}{l}\text { The regulatory body has } \\
\text { authority over online practice } \\
\text { within Ontario, therefore reg- } \\
\text { istration/licensure is required. } \\
\text { But since it does not have } \\
\text { legal authority over social } \\
\text { workers practising outside } \\
\text { of Ontario, it is unable to } \\
\text { address complaints from a } \\
\text { client outside of Ontario. } \\
\text { Ontario College of Social } \\
\text { Workers and Social Service } \\
\text { Workers } \\
\text { (teleconference on March } \\
\text { 30, 2011) }\end{array}$ & $\begin{array}{l}\text { The issue is being studied } \\
\text { at the committee level, and } \\
\text { there is currently a provision } \\
\text { on electronic practice in the } \\
\text { draft Professional Misconduct } \\
\text { Regulation. Professional mis- } \\
\text { conduct in clinical practice } \\
\text { in Ontario includes providing } \\
\text { services electronically with- } \\
\text { out explicit client consent or } \\
\text { without appropriate insurance } \\
\text { coverage. Currently, Ontario } \\
\text { does not have a specific posi- } \\
\text { tion or policy on electronic } \\
\text { practice. } \\
\text { Transitional Council of } \\
\text { the College of Registered } \\
\text { Psychotherapists and } \\
\text { Registered Mental Health } \\
\text { Therapists of Ontario } \\
\text { (e-mail response on May } 30 \text {, } \\
\text { 2011) }\end{array}$ & $\begin{array}{l}\text { One must be registered in } \\
\text { the jurisdiction in which the } \\
\text { client resides, as the service } \\
\text { is considered to be delivered } \\
\text { in the location where the } \\
\text { client is. Only members of } \\
\text { the College of Psycholo- } \\
\text { gists of Ontario can provide } \\
\text { electronic psychological } \\
\text { services to clients in Ontario. } \\
\text { If a psychologist is in another } \\
\text { jurisdiction, registration in } \\
\text { Ontario would be necessary. } \\
\text { Ontario does not have a cour- } \\
\text { tesy register. } \\
\text { College of Psychologists in } \\
\text { Ontario } \\
\text { (e-mail response on April } \\
\text { 26, 2011) }\end{array}$ \\
\hline
\end{tabular}

Quebec No correspondence or identi-

Counselling and psychother-

No correspondence or identified guidelines on e-health apy are regulated in Quebec according to Bill 21. No guidelines on e-health were identified. Regulations bring about the same restriction as for psychologists.

Ordre des Psychologues du Québec, 2011

Prince Edward Island
No correspondence or identified guidelines on e-health
No correspondence or identified guidelines on e-health fied guidelines on e-health

No correspondence or identified guidelines on e-health 
Table 1

(continued)

\begin{tabular}{ll}
\hline Province & Social Workers \\
\hline New Brunswick & $\begin{array}{l}\text { It is the social worker's } \\
\text { responsibility to contact the } \\
\text { regulatory boards of intent } \\
\text { to provide services and find } \\
\text { out what requirements are } \\
\text { necessary to provide services } \\
\text { legally in those jurisdictions. } \\
\text { This could include a re- } \\
\text { quirement to register in the } \\
\text { jurisdiction where the client } \\
\text { is located. } \\
\text { New Brunswick Association } \\
\text { of Social Workers, 2010 }\end{array}$ \\
$\begin{array}{l}\text { Practice may be subject to } \\
\text { regulation in both the juris- } \\
\text { diction in which the client } \\
\text { receives services and the ju- } \\
\text { risdiction in which the social } \\
\text { worker provides the services. } \\
\text { Nova Scotia Association of } \\
\text { Social Workers, 2008 }\end{array}$ \\
$\begin{array}{l}\text { Notia } \\
\text { Noval }\end{array}$
\end{tabular}

Newfoundland and Labrador
Counsellors
Psychologists

No correspondence or identified guidelines on e-health

No correspondence or identified guidelines on e-health
No correspondence or identified guidelines on e-health

No correspondence or identified guidelines on e-health 
Table 1

(continued)

\begin{tabular}{|c|c|c|c|}
\hline Province & Social Workers & Counsellors & Psychologists \\
\hline $\begin{array}{l}\text { National } \\
\text { Regulatory Body } \\
\text { or Associations }\end{array}$ & $\begin{array}{l}\text { CASW does not have any } \\
\text { guidelines on e-health } \\
\text { Canadian Association of } \\
\text { Social Workers }\end{array}$ & $\begin{array}{l}\text { CCPA does not have a } \\
\text { specific position at this point } \\
\text { other than to try to educate } \\
\text { its members about the legal } \\
\text { complexities of working } \\
\text { across borders. A draft of a } \\
\text { document describing the legal } \\
\text { issues that counsellors may } \\
\text { face if they use technology } \\
\text { to provide "e-counselling" is } \\
\text { available for review. } \\
\text { Canadian Counselling and } \\
\text { Psychotherapy Association } \\
\text { (CCPA) } \\
\text { (e-mail response on May 4, } \\
\text { 2011) }\end{array}$ & $\begin{array}{l}\text { There is not going to be any } \\
\text { change to the position that } \\
\text { the psychologist must be } \\
\text { registered in the jurisdiction } \\
\text { in which the recipient lives. } \\
\text { There was discussion of a } \\
\text { temporary licence to prac- } \\
\text { tise in other provinces "for } \\
\text { purposes of on-line support } \\
\text { group facilitation only [as } \\
\text { long as the psychologist isn't } \\
\text { actually running an office } \\
\text { practice]" at a lower cost but } \\
\text { this is currently unresolved. } \\
\text { Association of Canadian } \\
\text { Psychology Regulatory } \\
\text { Organizations (ACPRO) } \\
\text { (e-mail response on May } 3 \text {, } \\
\text { 2011) } \\
\text { Psychologists are required } \\
\text { to be licensed or certified in } \\
\text { any jurisdiction that requires } \\
\text { licensure or certification } \\
\text { of psychologists providing } \\
\text { e-services to persons who } \\
\text { reside in that jurisdiction. } \\
\text { Canadian Psychological } \\
\text { Association (CPA), 2006 }\end{array}$ \\
\hline
\end{tabular}

In British Columbia, there is recognition of the potential of technology to help counsellors assist their clients. However the new policy guidelines (British Columbia Association of Clinical Counsellors, 2011) that have replaced the previous, more conservative ones (British Columbia Association of Clinical Counsellors, 1996) still struggle with the locus of therapy for telephone or internet counselling. Although Ontario is studying electronic practice at the committee level, no resolution has yet been reached regarding a policy or position statement (Transitional Council of the College of Registered Psychotherapists and Registered Mental Health Therapists of Ontario, personal communication, May 30, 2011).

Currently, the Canadian Counselling and Psychotherapy Association (CCPA) does not have a specific position other than to try to educate its members about the legal complexities of working across borders. 
A draft document from their legal department described some of the issues that counsellors may face if technology is used to provide "e-counselling"-complaint resolutions, self-protection, certification, and insurance (Canadian Counselling and Psychotherapy Association, personal communication, May 4, 2011). CCPA is lobbying to develop and implement a "national definition and scope of practice" that would pertain to mobility of counsellors between provinces (Canadian Counselling and Psychotherapy Association, 2007).

No policies or guidelines on online practice could be identified for the associations of Alberta, Saskatchewan, Manitoba, New Brunswick, Nova Scotia, Prince Edward Island, and Newfoundland and Labrador. Also, we could not establish contact with key informants from these organizations.

Psychology. A thorough search of the websites of the regulatory colleges of psychologists yielded no information on telehealth or e-health except for the Nova Scotia Board of Examiners in Psychology (2010). The practice of psychology is regulated in all ten provinces and the Northwest Territories. At the moment, all the Canadian jurisdictions appear to be struggling with the issue of tele-psychology and how to regulate those who practise it in Canada. It is a multifaceted issue with implications for all parties that might be involved in an allegation or complaint. Through individual e-mail communications with the respective regulatory colleges, some insights were gained about the challenges in practising cross-provincially (such as moderating online support groups) for psychologists (Table 1).

In Ontario, Newfoundland and Labrador, and Nova Scotia, psychologists are required to register in the province of the client in order to deliver e-services (Table 1). Currently, the Association of Canadian Psychology Regulatory Organizations (ACPRO) has maintained its position that there will not be any change to the regulation that the psychologist must be registered in the jurisdiction in which the recipient lives (Figure 1). There was discussion of temporary licence to practise in other provinces "for purposes of on-line support group facilitation only, as long as the psychologist isn't actually running an office practice at a lower cost," but this issue is currently unresolved (Association of Canadian Psychology Regulatory Organizations, personal communication, May 3, 2011).

No policies or guidelines on online practice could be identified for the regulatory colleges of British Columbia, Alberta, Saskatchewan, Manitoba, Quebec, New Brunswick, and Prince Edward Island. Correspondence with some of these organizations was not reciprocated while others quoted the position statement of ACPRO as their organization's position on e-health.

\section{DISCUSSION}

\section{Integration and Implications of Current Canadian Guidelines for Community Mental Health Practice}

As can be seen from this review and environmental scan, online delivery of psychosocial care, such as the professionally-led OSGs offered through our initiative, is at the centre of much debate and dilemma. Although practitioners and organizations are seeking clarity and consistency in the guidelines for online practice, there is a lack of communication between regulatory bodies. Therefore, position statements and policies emerging seemed to be unevenly informed and not keeping pace with the technology or service needs of the population. While some professional associations provide very clear guidelines for practice conducted via the internet and telephone (Canadian Nurses Association, 2007), others 
vary across province or go so far as to recommend avoiding online practice (British Columbia Association of Clinical Counsellors, 1996). Apart from the CNA position statement, no progress has been made with regard to interjurisdictional e-practice.

Online psychosocial care is part of a broader e-health initiative and therefore also dependent on general e-practice guidelines. Organizations such as the National Institute for Telehealth (NIFTE) and the B.C. Alliance on Telehealth Policy and Research (BCATPR) are advocacy groups that have examined and provided insight and recommendations regarding a number of e-health related policy issues, in areas including organization, human resources, technology and equipment, and clinical standards and outcomes issues (National Initiative for Telehealth Guidelines, 2003; Scott, 2008). In a baseline study published by BCATPR, the barriers to policy development were associated with lack of identified need, lack of standardized process, improper allocation of resources, remuneration, ineffective communication, conflicting ideologies, ambiguity of roles, political issues, and connectivity. This study also points out that "telehealth is inherently inter-jurisdictional in its application and impact, and therefore it is essential to develop policy in an inter-jurisdictional manner" (Scott, 2008).

In 2004, a status report on telemental health in Canada (Health Canada, Information, Analysis and Connectivity Branch, Health and the Information Highway Division, 2004) showed that numerous jurisdictional activities and cross-jurisdictional partnerships were percolating in an effort to make specialized services available to all Canadians. This report identified some "work arounds" that were used to support telemental health practice across jurisdictional boundaries, such as recruiting practitioners who can practise in more than one province by following normal referral patterns and assigning limited "privileges" to those practices cross-provincially. However, these jerry-rigged arrangements were only effective during the early development stage, when clinical activities were manageable. With the current high demand for mental health services online, permanent, harmonized, and well-thought-through solutions are needed.

Firstly, based on this review, it is apparent that the provincial boards are essentially working independently. Apart from psychologists and nurses, professions involved in online psychosocial care in Canada do not have Canada-wide advisory bodies to address the issues of online practice at a national level (Figure 1). Existing decisions are seemingly being taken by individual jurisdictions, mostly independent from one another and without knowledge of one another's current position on the matter. Consequently, guidelines for online practice, if there are any, are mixed, and emerging policy statements remain unharmonized. Furthermore, although national e-health/telehealth organizations with knowledge about these issues exist, the provincial regulatory bodies have not sought guidance or consultation despite telehealth having long ago identified the pertinent issues and solutions. The problem with the status quo is that an inappropriate and disjointed policy in any single jurisdiction may impede the ability of e-health to fulfill its potential.

Secondly, the professions of psychology, social work, and counselling are moving towards the adoption of restrictive positions (Table 1). This may be due in part to a lack of knowledge of existing practice guidelines and research evidence (Wells et al., 2007). But it appears that the primary concern is that they do not know how to resolve the issue of accountability and the dilemma of "where therapy resides" in online practice. If a patient lodges a complaint, who is responsible for investigating it, and who has authority to follow up? The solution being implied or suggested —obtaining multiple licences to practise in different 
provinces - is impractical and puts an undue burden of responsibility and cost on the provider. ACPRO has taken the most explicit position, stating that online providers should be registered with the regulatory body where the client or patient resides. This guideline has now been adopted by several provincial colleges of psychology across Canada and applies to online interventions including support groups for cancer patients.

In addition to being impractical, this practice-limiting position effectively prevents psychologists from participating in the kinds of national forms of e-therapy or online support that might be most effective at reaching hard-to-reach and underserved people in any province or territory. We question whether the focus on issues of professional liability and the reluctance of regulatory bodies to address those issues should be the determining factor. This approach could be understood to violate a foundational ethical principle - that of maximizing benefit to those seeking or needing psychological services - and could be an impediment to realizing the goal of ensuring that all Canadians are able to access the care they require.

\section{Recommendations Towards Policies for Online Psychosocial Care}

In bringing this analysis back to the case of online support groups, of which we have extensive familiarity and expertise, it could be argued that such groups are merely supportive or psycho-educational and not intended as psychotherapy, hence possibly limiting the legal and ethical constraints on the services they provide (Stephen et al., 2013). However, the authors do not think this solution is generalizable or adequate and are advocating for more inclusive policies and guidelines that address all types of online psychosocial care. To keep up with patient and client demand and expectation and the stride of technology, longer-term and carefully thought-out measures that take into account regulatory burden and unintended destructive consequences are warranted.

In their discussion paper on telehealth, Pong and Hogenbirk (1999) present various policy options for telemedicine licensure, including the use of national licensure, the creation of a special licence for telemedicine, mutual recognition, and endorsement. Although we see their licensure models as useful in circumventing jurisdictional issues, we believe that defining the jurisdiction of therapy by the location of patients adds an unnecessary layer of complexity to the licensure issue and deprives therapy consumers of choice which rightfully belongs to them. One concrete example is telemedicine: Even though the medical field pioneered telehealth, it is still struggling with heterogeneous policies and positions on the matter of cross-provincial delivery of care (Donahue, 2009).

Advocacy groups such as the International Society for Mental Health Online (ISMHO) have put forward some principles and guidelines to facilitate integration of online communication, information, and technology for the international mental health community. However, licensure issues are still not fully addressed in these guidelines (International Society for Mental Health Online, 2000). Insights from Australia, a country comparable to Canada in its vastness where e-therapy is prominent (Gedge, 2002) and supported by the Australian Psychological Society, can further guide the Canadian initiative. Since Australia and some European countries such as the United Kingdom are not bound by the same licensure regimes as Canada or the United States (Mulhauser, 2011), interstate or interprovincial practice is not an issue. We are not suggesting eliminating licensure regulations in North America but instead propose tailoring policies and guidelines so that they can better align with the potential of e-health. If an agreement cannot be reached on 
national licensure, there could always be an agreement on national guidelines for online delivery of health care. Issues pertaining to resolution of patients' complaints and licensure need to be addressed at a national level because the scope of this online health service transcends jurisdictional boundaries.

Results of this environmental scan have supported the conclusion that locating the mental health service with the practitioner (rather than the patient/consumer) is the most adaptable model transcending jurisdictional boundaries while ensuring that the interests of clients or patients are safeguarded. This position is consistent with our own experiences running pan-Canadian OSGs and with the position of the CNA. National organizations such as ACPRO, FMRAC, and CCPA can use the CNA position statement as a scaffold to develop national policies for online practice that will override current provincial policy patchworks and harmonize e-health practice across provincial boundaries.

In the case of online delivery of care, the locus of practice should be where the mental health practitioner is registered and resides. In this licensure model, the client is in effect "electronically transported" to the e-health provider to receive services. Therefore, the regulatory bodies where the practitioner is registered should make arrangements to deal with all complaints both in province and out of province. The implementation of such a policy would require a pan-Canadian approach, and regulatory bodies should be willing to work together on how to address out-of-province complaints regarding practitioners involved in online psychosocial care.

This review has several limitations. Slightly fewer than $40 \%$ of the key informants replied to our request for an interview, so our analyses might not be comprehensive. The request was sent by a research assistant on behalf of the team, whereas a more formal request from the partner organizations might have yielded a higher response. The review of the available guidelines was limited to issues concerning cross-jurisdictional practice regulation; it did not investigate other obstacles to the delivery of online care such as reimbursement and implementation cost. Further analysis of the statements for other topics such as ethical issues, appropriate interventions, and appropriate populations would provide a more informed understanding of these statements and help shape future ones.

\section{CONCLUSION}

Online psychosocial care is an e-health network of practice that connects the patient to the provider and can facilitate the delivery of health care across a range of boundaries and obstacles. While e-health is based on technology that transcends jurisdictional boundaries, the practice of e-health is still accountable to provincial regulatory bodies and, therefore, limited by geographical boundaries. This review of e-counselling policies complements the telemedicine review by Donahue (2009), which has shown that professional regulations across Canada have not kept pace with technological advancement and have been identified as barriers to the development of e-health including online psychosocial care. Furthermore, the lack of online practice guidelines or knowledge on the matter may have led to ad hoc position statements that are both restrictive and contrary to the Canadian health mandate of making care accessible to all Canadians. There is a need to update regulations so that they match the stride of technological innovation when it supports patient-centred care delivery. Regulatory reform may be guided by principles which encourage the use of electronic communication that is therapeutically effective and may require greater cooperation and coordination between 
regulatory bodies to find innovative solutions that are in keeping with the promise of the technology and the needs of Canadians.

\section{REFERENCES}

Alberta College of Social Workers. (2007). Standards of practice. Retrieved from http://www.acsw.ab.ca/social_workers/ practice_resources/standards_of_practice_1

Alleman, J. R. (2002). Online counseling: The internet and mental health treatment. Psychotherapy: Theory, Research, Practice, Training, 39(2), 199. doi: 10.1037/0033-3204.39.2.199

Barak, A., Klein, B., \& Proudfoot, J. G. (2009). Defining internet-supported therapeutic interventions. Annals of Behavioral Medicine: A Publication of the Society of Behavioral Medicine, 38(1), 4-17. doi: 10.1007/s12160-009-9130-7

Bloom, J. W. (1998). The ethical practice of Web counseling. British Journal of Guidance \& Counselling, 26(1), 5359. doi: 10.1080/03069889808253838

British Columbia Association of Clinical Counsellors. (1996). A policy statement for counselling via telephone or computer technology. Retrieved from http://bcacc.tacticaic.com/general/code-of-ethical-conduct-and-standards-of-clinicalpractice\#telecounsel

British Columbia Association of Clinical Counsellors. (2011). Standard for the use of technology in counselling. Retrieved from http://bc-counsellors.org/wp-content/uploads/2011/02/7BCACC-Standard-Use-of-Technology-2011.pdf

Canada. (1984/1985). Canada Health Act. R.S.C. 1985, ch. C-6.

Canada Health Infoway. (2011). Telehealth benefits and adoption: Connecting people and providers across Canada. Retrieved from https://www2.infowayinforoute.ca/Documents/telehealth_report_2010_en.pdf.

Canadian Counselling and Psychotherapy Association. (2007). Inter-provincial mobility initiative. Retrieved March 20, 2013, from http://www.ccpa-accp.ca/en/symposium2011/

Canadian Counselling and Psychotherapy Association. (2011). July 2011 update on Quebec Bill 21 - psychotherapy. Retrieved from http://www.ccpa-accp.ca/_documents/JULY2011UPDATEONQUEBECBILL21.pdf

Canadian Nurses Association. (2007). Telehealth: The role of the nurse. Retrieved from http://www.cna-nurses.ca/can/ documents/pdf/publications/ps89_telehealth_e.pdf

Collège des Médecins du Québec. (2000). Telemedicine. Retrieved from http://www.cmq.org/en/MedecinsMembres/ Profil/Commun/AProposOrdre/Publications/ /media/Files/Positions/Position\%20telemedecine\%20ang\%202000. pdf?31320

College of Physicians and Surgeons of Alberta. (2000, September). Council passes telemedicine bylaw. The Messenger, 81, 8-9. Retrieved from http://www.cpsa.ab.ca/Libraries/Res_Messenger/m081.pdf

Derrig-Palumbo, K. (2009). Considerations for MFTs working with clients online. Family Therapy Magazine, 8, 24-27.

Donahue, M. (2009). Licensure and telemedicine: National review of policies. Telehealth Law, 10, 24-27.

Federation of Medical Regulatory Authorities of Canada. (2010). FMRAC policy on telemedicine. Retrieved March 20, 2013, from http://www.fmrac.ca/policy/telemedicine.html

Fernsler, J. I., \& Manchester, L. J. (1997). Evaluation of a computer-based cancer support network. Cancer Practice, $5(1), 46-51$.

Finfgeld, D. L. (2000). Therapeutic groups online: The good, the bad, and the unknown. Issues in Mental Health Nursing, 21(3), 241-255.

Fox, S., \& Purcell, K. (2010). Chronic disease and the internet. Research report. Washington, DC: Pew Research Center. Retrieved from http://www.pewinternet.org/ /media//Files/Reports/2010/PIP_Chronic_Disease_with_topline.pdf

Gedge, R. (2002). Online counselling services in Australia - the challenges of a new vehicle for an old art. Retrieved from http://ausweb.scu.edu.au/aw02/papers/refereed/gedge2/paper.html

Gustafson, D. H., Hawkins, R., Pingree, S., McTavish, F., Arora, N. K., Mendenhall, J., . . Salner, A. (2001). Effect of computer support on younger women with breast cancer. Journal of General Internal Medicine, 16(7), 435-445. doi: 10.1046/j.1525-1497.2001.016007435.x

Gustafson, D., Wise, M., McTavish, F., Taylor, J. O., Wolberg, W., Stewart, J., . . Bosworth, K. (1994). Development and pilot evaluation of a computer-based support system for women with breast cancer. Journal of Psychosocial Oncology, 11(4), 69-93. doi: 10.1300/J077V11N04_05 
Health Canada, Information, Analysis and Connectivity Branch, Health and the Information Highway Division. (2004). Telemental health in Canada: A status report. Retrieved from http://publications.gc.ca/pub?id=267313\&sl=0

Houston, T. K., Cooper, L. A., \& Ford, D. E. (2002). Internet support groups for depression: A 1-year prospective cohort study. American Journal of Psychiatry, 159(12), 2062-2068. doi: 10.1176/appi.ajp.159.12.2062

Hoybye, M. T., Johansen, C., \& Tjornhoj-Thomsen, T. (2005). Online interaction. effects of storytelling in an internet breast cancer support group. Psycho-Oncology, 14(3), 211-220. doi: 10.1002/pon.837

International Society for Mental Health Online. (2000). Suggested principles for the online provision of mental health services. Retrieved from https://www.ismho.org/suggestions.asp

Kates, N., Gagné, M., \& Whyte, J. M. (2008). Collaborative mental health care in Canada: Looking back and looking ahead. Canadian Journal of Community Mental Health, 27(2), 1-4.

Klemm, P., Bunnell, D., Cullen, M., Soneji, R., Gibbons, P., \& Holecek, A. (2003). Online cancer support groups: A review of the research literature. Computers Informatics Nursing, 21(3), 136.

Lester, D. (2006). E-therapy: Caveats from experiences with telephone therapy. Psychological Reports, 99(3), 894-896. doi: 10.2466/PR0.99.3.894-896

Lieberman, M. A., \& Golant, M. (2002). Leader behaviors as perceived by cancer patients in professionally directed support groups and outcomes. Group Dynamics: Theory, Research, and Practice, 6(4), 267. doi: 10.1037/1089-2699.6.4.267

Lieberman, M. A., Golant, M., Giese-Davis, J., Winzlenberg, A., Benjamin, H., Humphreys, K., . . Spiegel, D. (2003). Electronic support groups for breast carcinoma: A clinical trial of effectiveness. Cancer, 97(4), 920-925. doi: 10.1002/cncr.11145

Lieberman, M. A., Winzelberg, A., Golant, M., Wakahiro, M., DiMinno, M., Aminoff, M., \& Christine, C. (2005). Online support groups for Parkinson's patients: A pilot study of effectiveness. Social Work in Health Care, 42(2), 23-38. doi: 10.1300/J010v42n02_02

Maheu, M. M. (2003). The online clinical practice management model. Psychotherapy: Theory, Research, Practice, Training, 40(1-2), 20-32. doi: 10.1037/0033-3204.40.1-2.20

Mallen, M. J., Vogel, D. L., \& Rochlen, A. B. (2005). The practical aspects of online counseling ethics, training, technology, and competency. The Counseling Psychologist, 33(6), 776-818. doi: 10.1177/0011000005278625

McTavish, F., Gustafson, D., Owens, B., Hawkins, R., Pingree, S., Wise, M., . . Apantaku, F. (1995). CHESS (comprehensive health enhancement support system): An interactive computer system for women with breast cancer piloted with an underserved population. Journal of Ambulatory Care Management, 18(3), 35.

Mulhauser, G. (2011). Professional licensing in mental health. Retrieved from http://counsellingresource.com/lib/ therapy/aboutcouns/licensure/

Mulvale, G., \& Bartram, M. (2009). Recovery in the Canadian context: Feedback on the framework for mental health strategy development. Canadian Journal of Community Mental Health, 28(2), 7-15.

National Initiative for Telehealth Guidelines. (2003). National initiative for telehealth (NIFTE) framework of guidelines. Retrieved from http://dspace.ucalgary.ca/bitstream/1880/42967/3/NIFTEguidelines2003eng.pdf

New Brunswick Association of Social Workers. (2010). Standards for the use of technology in social work practice. Retrieved from http://www.nbasw-atsnb.ca/download/standards/Standards\%20for\%20the\%20use \%20of\%20 technology_ENG.pdf

Nova Scotia Association of Social Workers. (2008). Standards of practice. Retrieved from http://nsasw.org/files/File/ standards\%20October\%2011,\%202008\%20finished\%20document\%20corrected\%20November\%202008.pdf

Nova Scotia Board of Examiners in Psychology. (2010). Provisjon of psychological services via electronic means. Retrieved from http://www.nsbep.org/downloads/Provision_of_Services_via_Electronic\%20Means.pdf

Pfeil, U., \& Zaphiris, P. (2010). Applying qualitative content analysis to study online support communities. Universal Access in the Information Society, 9(1), 1-16. doi: 10.1007/s10209-009-0154-3

Pong, R. W., \& Hogenbirk, J. C. (1999). Licencing physicians for telehealth practice: Issues and policy options. Health Law Review, 8(1), 3-13.

Rains, S. A., \& Young, V. (2009). A meta-analysis of research on formal computer-mediated support groups: Examining group characteristics and health outcomes. Human Communication Research, 35(3), 309-336. doi: 10.1111/j.1468-2958.2009.01353.x 
Scott, R. (2008). Telehealth policy baseline study. Retrieved from http://www.bcatpr.ca/ehealth_policy_study

Seale, C. (2006). Gender accommodation in online cancer support groups. Health, 10(3), 345-360. doi: $10.1177 / 1363459306064495$

Sharf, B. F. (1997). Communicating breast cancer on-line: Support and empowerment on the internet. Women \& Health, 26(1), 65-84. doi: 10.1300/J013v26n01_05

Shaw, H. E., \& Shaw, S. F. (2006). Critical ethical issues in online counseling: Assessing current practices with an ethical intent checklist. Journal of Counseling \& Development, 84(1), 41-53. doi: 10.1002/j.1556-6678.2006.tb00378.x

Skinner, A. E., \& Latchford, G. (2006). Attitudes to counselling via the internet: A comparison between in-person counselling clients and internet support group users. Counselling and Psychotherapy Research, 6(3), 158-163. doi: 10.1080/14733140600853641

Stephen, J., Rojubally, A., MacGregor, K., McLeod, D., Speca, M., Taylor-Brown, J., . . Sellick, S. (2013). Evaluation of CancerChatCanada: A program of online support for Canadians affected by cancer. Current Oncology, 20(1), 39. doi: $10.3747 / \operatorname{co} .20 .1210$

Sullivan, C. F. (2003). Gendered cybersupport: A thematic analysis of two online cancer support groups. Journal of Health Psychology, 8(1), 83-104. doi: 10.1177/1359105303008001446

Weinberg, N., Schmale, J. D., Uken, J., \& Wessel, K. (1995). Computer-mediated support groups. Social Work with Groups, 17(4), 43-54. doi: 10.1300/J009v17n04_04

Weinberg, N., Schmale, J., Uken, J., \& Wessel, K. (1996). Online help: Cancer patients participate in a computermediated support group. Health \& Social Work, 21(1), 24-29. doi: 10.1093/hsw/21.1.24

Wells, M., Mitchell, K. J., Finkelhor, D., \& Becker-Blease, K. A. (2007). Online mental health treatment: Concerns and considerations. CyberPsychology \& Behavior, 10(3), 453-459. doi:10.1089/cpb.2006.9933

Winzelberg, A. J., Classen, C., Alpers, G. W., Roberts, H., Koopman, C., Adams, R. E., . . Taylor, C. B. (2003). Evaluation of an internet support group for women with primary breast cancer. Cancer, 97(5), 1164-1173. doi: 10.1002/cncr.11174 